\title{
Quarantining activism: COVID-19, frontline defenders and intensifying extractivism in the Philippines
}

\author{
Wolfram Dressler ${ }^{1}$ \\ Melbourne, Australia
}

\begin{abstract}
How does the intersection of authoritarian populism and a global pandemic reinforce the suppression of human rights, dismantle environmental protections, and accelerate resource extraction? In parts of Southeast Asia, the rise of authoritarian regimes has created conditions of impunity in which state and non-state actors have exploited restrictions during the COVID-19 pandemic to restrain activism, contain indigenous livelihoods, and intensify resource exploitation. This article explores how political control and violence against activists ('defenders') under authoritarian Philippine President Rodrigo Duterte have intersected with and been reinforced through COVID-19 health measures to curtail grass-roots efforts to protect social and environmental safeguards. Since March 2020, violence against defenders has gone viral as activism in the country has been quarantined. Under Duterte's authoritarian populist rhetoric, state actors, parastatal and shadowy assassins have allegedly used public health measures to suppress activism further, enabling the harassment, arrests, and deaths of defenders and the intensification of resource extraction. Based on a critical review of news media and conservation policy, I describe the history and current context of defenders being 'quarantined' by authorities using lockdown measures to coercively suppress social and environmental activism across the country. I examine cases from Palawan Island to show how political authorities and elites have used COVID-19 to suppress defender mobility and enforcement practices and how lulls in defending and discourses of 'pandemic recovery' have facilitated mining and deforestation. The conclusion asserts that paying attention to how political conjunctures produce violent governance and local resistance reveals civil society's crucial role and vulnerabilities in protecting human rights and the environment in the Philippines and Southeast Asia.
\end{abstract}

Key Words: state violence, Philippines, pandemic, environmental activism, defenders

\section{Résumé}

Comment le populisme autoritaire et une pandémie mondiale se croisent-ils pour renforcer puissamment la suppression des droits de l'homme, démanteler les protections environnementales et accélérer l'extraction des ressources? Dans certaines parties de l'Asie du Sud-Est, la montée des régimes autoritaires a créé des conditions d'impunité. Les acteurs étatiques et non étatiques ont exploité les restrictions pendant la pandémie de COVID19 pour restreindre l'activisme, contenir les moyens de subsistance autochtones et intensifier l'exploitation des ressources. Cet article explore comment le président autoproclamé autoritaire Rodrigo Duterte aux Philippines a déclenché un programme punitif de contrôle politique et de violence contre les militants (" défenseurs »). Cela a recoupé et exploité les mesures de santé publique pendant COVID-19 pour réduire les efforts de base pour protéger les garanties sociales et environnementales. Depuis mars 2020, la violence contre les défenseurs est littéralement devenue virale alors que l'activisme dans le pays est mis en quarantaine. Sous la rhétorique autoritaire de Duterte, des acteurs étatiques et des tueurs à gages parapublics et clandestins facilitant son programme, auraient utilisé des mesures de santé publique pour réprimer davantage l'activisme, permettant le harcèlement, les arrestations et la mort de défenseurs, et l'intensification de l'extraction des ressources. Sur la base d'une analyse critique des reportages des médias nationaux et de la politique de conservation, j'examine l'histoire et le contexte actuel des défenseurs « mis en quarantaine » par les autorités utilisant des mesures de verrouillage pour réprimer l'activisme social et environnemental à travers le pays. J'examine ensuite une série de cas de l'île de Palawan pour montrer comment les autorités politiques et les élites ont utilisé COVID-19 pour réprimer les mobilités des défenseurs et les pratiques d'application de la loi. Certaines accalmies dans la défense de l'environnement et les discours de « reprise en cas de pandémie » ont facilité l'exploitation minière et la déforestation. La conclusion affirme que prêter attention à la manière dont les conjonctures politiques produisent

\footnotetext{
${ }^{1}$ Dr. Wolfram Dressler, Melbourne, Australia. Email: dresslerwh "at" gmail.com. Acknowledgments: I thank an anonymous research assistant and two anonymous reviewers. All errors and omissions are my own.
} 
une gouvernance violente et une résistance locale révèle le rôle crucial de la société civile et sa vulnérabilité dans la protection des droits humains et de l'environnement aux Philippines.

Mots-clés: violence d'État, Philippines, pandémie, militantisme environnemental, défenseurs de l'environnement

\section{Resumen}

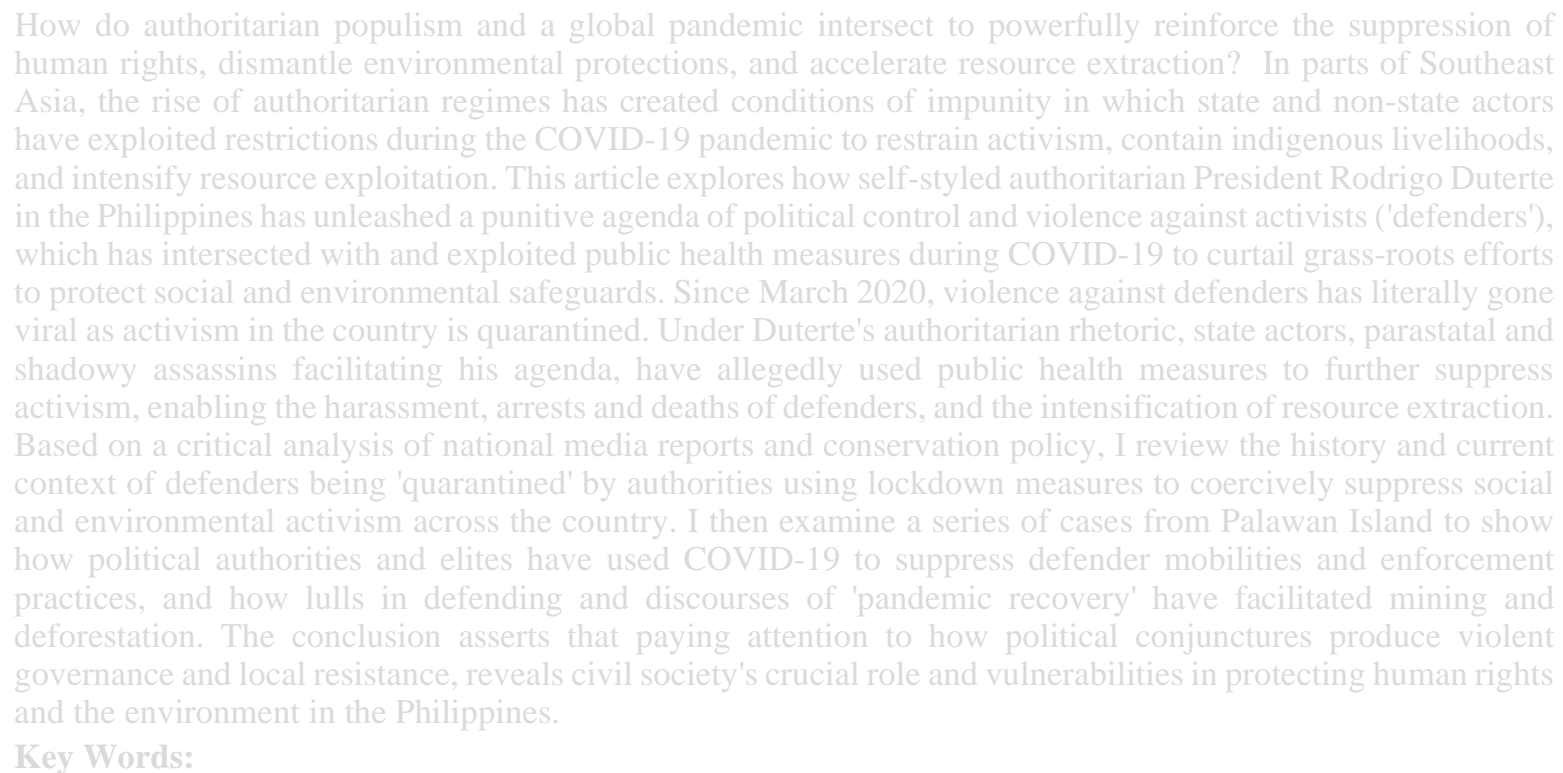

\section{Introduction}

How do authoritarian populism and a global pandemic intersect to reinforce the suppression of human rights, dismantle environmental protections, and intensify resource extraction? In parts of Southeast Asia, resurgent authoritarian regimes have created conditions of impunity in which state and non-state actors have intensified campaigns of intimidation, harassment, and murder of activists ('defenders') who uphold human rights and environmental protections (Beban et al., 2020; Middeldorp \& Billon, 2019; Neimark et al., 2019). A brand of authoritarian populism has emerged that aims to "construct around itself an active popular consent" (Hall 1979, 15) that legitimates economic expansion, political control and securitization through violent means and oppression of those failing to align with dominant state ideals. Since 2020, however, the outbreak of Severe Acute Respiratory Syndrome Coronavirus 2 (SARS-CoV-2) and the COVID-19 pandemic have enabled 'strongman' leaders, state actors (e.g., the military and police), and shadowy assassins in the region to exploit fraying legal orders and public health measures to restrain activism further, contain indigenous livelihoods and intensify illegal resource uses (e.g., timber poaching and mineral extraction). By critically examining national media and conservation policies, this article explores how the election of self-styled authoritarian President Rodrigo Duterte in the Philippines has generated punitive agendas of political control and violence, which have intersected with and harnessed COVID-19 health measures to coercively constrain defenders protecting social and environmental safeguards.

In 2020, the United Nation's Human Rights Council released a damning report stating that, between 2015 and 2019, at least 248 human rights and environmental defenders had been murdered in their pursuit of social and environmental justice in the Philippines (OHCHR, 2020). The incidents of harassment, intimidation and murder of so-called leftist defenders have increased considerably since President Duterte assumed office. Elected in 2016, President Duterte built upon exploitative resource policies and growth agendas of predecessors to exercise repressive political control with revanchist rhetoric and practices directed against actors in civil 
society critical of his rule. Partly emboldened by the President's violent rhetoric, state actors, political elites and assassins have intensified the routine practice of crushing activist dissent and social movements to enable private and state-financed resource grabbing and extractive development (mining, palm oil production etc.) in ways that intersect with and exacerbate communist and Moro-Islamic insurgencies in 'commodity frontiers' such as Mindanao and Palawan (Holden et al., 2011; Moore, 2000). With Duterte's ostensive pivot to the 'East', Chinesebacked loans have continued to finance his mega-infrastructure initiatives, driving palm oil plantations, roads and hydropower projects into frontier areas (Bello, 2019; Heydarian, 2017). The increase in bloodshed of defender deaths has spilled amidst state and non-state securitization measures that have long underpinned resource control and extractivism in the country (Delina, 2020).

In September 2016, Duterte declared a nationwide 'state of emergency' due to multiple insurgent bombings in Mindanao, which culminated in a declaration of martial law for the island. Declared in May 2017, martial law ran for 31 months. Defenders were criminalized as terrorists and subject to curfews, monitoring, arrests, and murder (Aspinwall, 2020a). According to the domestic NGO, Kalikasan People's Network for the Environment (KPNE, 2019) 46 defenders were killed in 2019, with the majority being activist farmers and/or plantation workers, followed by municipal officials, indigenous peoples and forest rangers. Duterte's Philippines is now one of the most dangerous countries in the world for human rights and environmental defenders: an 'accounting' that most likely underreports the numbers of killings and fails to lay bare the violent atmospheres behind the executions and harassment leading up to them (Mostafanezhad and Dressler, 2021).

While human rights and environmental activists have faced ongoing harassment and death by murder under previous state administrations, President Duterte's brutish populism has reinforced earlier political economies of violence to embolden the military, police and assassins to further unleash violence across the countryside. Many of these actors have intensified the decades-old practice of red-tagging Filipino defenders as leftist 'anti-capitalists' and presumed sympathizers of the New People's Army (NPA), the armed wing of the Communist Party of the Philippines (CPP). Red-tagging and similar schemes are part of broader surveillance and intimidation campaigns spreading across the country (Rutten, 2008; Holden et al., 2011).

Writing approximately six months after martial law was 'lifted' in Mindanao ${ }^{2}$, the state's Anti-terrorism Act (RA No. 11479) has further conflated terrorism and activism in law and practice, reinforcing the ongoing suppression of citizens' rights and freedoms (Aspinwall, 2020b). Under the law, the military and police now have sweeping powers to determine what constitutes terrorism, obliging 'suspects' to prove they have no connections with the CPP-NPA or other insurgency groups (many of whom have since been branded as terrorists) (Aspinwall, 2020b). With little independent judicial oversight, enforcement agencies and politicians have red-tagged almost anyone with activist inclinations - whether priest, farmer or fisher-as a potential terrorist threat (Chavez, 2020; Batac, 2020).

Since March 2020, however, the strategies and struggles of environmental and human rights defenders have entered the increasingly violent epoch of COVID-19. Between March 7 and 12, after a sudden increase in local transmission in Metropolitan Manila (a mega city of 24 million residents) and the World Health Organization declaring COVID-19 a global pandemic, health authorities in the Philippines suspended air, sea and land travel into and out of the National Capital Region (Palo et al., 2020, p. 169-170). On March 17, President Duterte declared the first 'enhanced community quarantine' (ECQ) for Metro Manila to contain the initial outbreak. Hard lockdowns were imposed across the islands of Luzon and Mindanao and the rest of the country in early April (Aspinwall, 2020c). Scheduled to end on April 12, ECQ was extended twice and continued until June $1^{\text {st }}$, after which restrictions were loosened under the general community quarantine scheme (Palo et al., 2020). Since then, various types of community quarantine have continued across the country. Subject to sustained emergency quarantines, the already dangerous work of defender activism has been subjected to further monitoring and restrictions that, depending upon who enforces the 'health measures' and the political context, increasingly targets and suppresses activism in the country.

\footnotetext{
${ }^{2}$ Duterte first imposed a state of emergency in Mindanao in September 2016 (Aspinwall, 2020b).
} 
In the context of pre-existing state controls, those enabling Duterte's agenda have used the spread of COVID-19 and associated quarantine laws to further suppress activism in rural and urban areas of the country (Aspinwall, 2020c). As certain state and non-state actors' use of COVID-19 restrictions has contained activism and frayed social and environmental protections, political elites, private sector actors, and local 'illegalista' have been emboldened to grab land, poach timber and non-timber forest products, and illegally harvest marine resources with fewer barriers in place. By quarantining and threatening defenders, illegal operators have taken advantage of lulls in enforcement and monitoring to accelerate resource plunder and further threaten the resource base and livelihoods of local and indigenous peoples. In other cases, the state and private sector have exploited COVID-related suppressions to further expand mining and palm oil plantations into the forested uplands as part of the country's so-called pandemic recovery.

Rather than examine definitive associations between COVID-19 restrictions and defender suppression, this article draws on news media sources to describe the emerging patterns of state and non-state actors allegedly using COVID-19 restrictions to accelerate the suppression of activism in the country and intensify resource exploitation in frontier areas. Such suppression has occurred through state authorities increasingly issuing fines and arresting defenders doing their work (e.g., mobilizing, collective protests, patrols) in apparent breach of quarantine restrictions. I show how the violent conjunctures of political oppression and COVID-19 restrictions have unfolded together to intensify the containment of defender activism, and how such suppression (and the ostensive push for recovery) has intensified the exploitation of natural resources on the province island of Palawan. I describe how long-standing autocratic governance on Palawan has now been partly exacerbated through the political interplay between Duterte's rhetorical violence and COVID-19 restrictions. Although political autocrats on Palawan have long resented the activist left, particularly in the wake of successful environmental campaigns, provincial politicians have now intensified their critical stance against civil society on the island. I then discuss plight on the plight of defenders in the medium-term under COVID-19 and what this means for the future of activism in the Philippines.

\section{Methods}

With a research assistant's help ${ }^{3}$, data were drawn from a standardized search of online news media sources from March to December 2020, the initial major period of COVID-19 outbreaks and sustained public health measures across the country. The sourcing of content related to the specific political entanglement of defender ${ }^{4}$ activism (concerning environmental degradation, land grabs, agrarian reform, and human rights abuses, etc.), state and non-state suppression, and COVID-19 public health restrictions.

Using the Google Advanced Search, we conducted a broader and more detailed search of mainstream news, national news, state-owned news, and alternative news media for different types of state and non-state violence perpetrated against defenders from March to December 2020. This scaled searched invariably picked up cases related to COVID-19, which were then categorized and examined in greater detail. The specific online archives are:

\footnotetext{
${ }^{3}$ The research assistant expressed a desire to remain anonymous.

${ }^{4}$ Various NGOs and UN agencies have framed the term 'defender' in a relatively broad manner. Global Witness (2014) uses the term 'environmental and land defender' to mean "people who take peaceful action to protect environmental or land rights, whether in their own personal capacity or professionally" (p. 23). The UN uses the broader term 'environmental human rights defenders' (EHRD) to refer to "individuals and groups who, in their personal or professional capacity and in a peaceful manner, strive to protect and promote human rights relating to the environment, including water, air, land, flora and fauna" (UNE, 2018). This media review and analysis drew on a similarly broad definition of environmental and human rights defenders: all those (e.g., NGO staff, lawyers, indigenous farmers and fishers, park rangers, local politicians, mothers, fathers, brothers, sisters etc) who work in different capacities to protect and promote human rights and the environment in the context of suppression under authoritarian rule, or otherwise. I use the term 'defender' as shorthand for 'environmental and human rights defenders.'
} 
Mainstream national news media

- https://www.inquirer.net/ (Philippine Inquirer)

- https://mb.com.ph/ (Manila Bulletin)

- https://rappler.com/ (Rippler)

- https://www.philstar.com/ (Philippine Star)

State-owned news media, national

- https://www.pna.gov.ph/

Alternative news media, national

- https://www.altermidya.net/

During various online brainstorming discussions, the research assistant and I identified the following broader keywords and specific keyword strings for the analysis (Table 1):

\begin{tabular}{|l|l|l|}
\hline \multicolumn{2}{|l|}{ Step 1 - Identify keywords for Google Search } \\
\hline Main Keyword & Related phrases used in news media \\
\hline Environmental defender & Environmentalist, activist, NGO, community worker, indigenous \\
\hline Violence against & Arrested, harassed, dead, killed, threatened, detained, shot \\
\hline COVID-19 & Pandemic, quarantine restrictions, lockdown, activists \\
\hline Step 2 & - Formulate keyword strings for & Advanced Search \\
\hline$\# 1$ & Activist & Arrested OR dead OR killed OR threatened OR detained OR shot \\
\hline$\# 2$ & Environmentalist & Arrested OR dead OR killed OR threatened OR detained OR shot \\
\hline$\# 3$ & NGO & Arrested OR dead OR killed OR threatened OR detained OR shot \\
\hline$\# 4$ & Indigenous group & Arrested OR dead OR killed OR threatened OR detained OR shot \\
\hline$\# 5$ & Community leader & Arrested OR dead OR killed OR threatened OR detained OR shot \\
\hline$\# 6$ & Forest ranger & Arrested OR dead OR killed OR threatened OR detained OR shot \\
\hline$\# 7$ & Farmer & Arrested OR dead OR killed OR threatened OR detained OR shot \\
\hline Step 3 - Formulate keyword strings for Advanced Search \\
\hline$\# 8$ & COVID-19 & $\begin{array}{l}\text { Pandemic/ activist OR quarantine/ activist OR lockdown/ activist/ } \\
\text { detained }\end{array}$ \\
\hline
\end{tabular}

Table 1: Keywords and specific keyword strings used.

We then conducted the Google Advanced Search involving a content analysis of textual material related to the arrests, harassment and or murder of defenders independent of and in relation to COVID-19. The content analysis was further broken down by the type of incident, number of incidents reported, number of persons involved, and specific cases involving COVID-19 restrictions. To capture any potential outlier cases, we used MS Excel to document and examine regional media at the provincial level. We collated key patterns in the search across each media source to inform the broader narrative and details of specific cases in the article. Independent of the structured media review, I also drew on purposefully chosen case material from the local broadsheet, the Palawan Times, involving defenders being subjected to COVID-19 lockdowns and the associated rise in resource exploitation on Palawan. I contextualize these media cases with my own insights from my longer-term research on the island. Other cases of harassment and murder on the island unrelated to COVID-19 are described in Dressler (2021) and not discussed in this article. 


\section{Authoritarianism and the violence of viral conjunctures}

The global surge in authoritarian populism this past decade has extended political economic control and violence over people and territory to enable the expansion of ideology, capital, and resource development (Scoones et al., 2018; McCarthy, 2019; Middeldorp \& Billon, 2019). Based on his own reflections on authoritarian populism in the UK from the 1970s - 1980s, Stuart Hall's (1979) critique and conceptualisation of authoritarian populism resonates with the political and economic conjunctures in the Philippines that led to the rise of Duterte and before him, dictator Ferdinand Marcos in 1965. In Hall's formulation, authoritarian populism amounts to "an exceptional form of capitalist state-which, unlike classical fascism, has retrained most (though not all) of the formal representative institutions in place, and which at the same time has been able to construct around itself an active popular consent" (Hall 1979, p. 15). In the Philippines under Duterte, this active popular consent is upheld by and cuts across Filipinos of varying ethnicities, genders and classes, who have consistently supported the current president (Curato, 2016).

As exemplified by Duterte, recent scholarly work on authoritarian populism emphasizes a core trait of political performance and enactment engendered by certain styles and rhetorical practices imbued with revanchism and chauvinism (Moffitt and Tormey, 2014; Theriault, 2020). Authoritarian populists can often rely heavily on 'performative repertoires' in their claims to represent 'the people' or 'the nation' (ibid pp. 387-388) as they rely on varied tools of repression (e.g., militarized violence and diminishing civil liberties, etc.). Whether on the left or the right, charismatic politicians often harness the often-vague rhetorical tone of populism for instrumental means and ends, such as retaining power or staying in office (Bugaric, 2019). Some scholars have suggested that recent forms of authoritarian populism reflect a newer confrontational style that aims to meld and accentuate the aspirations and sentiments of broader public grievances, however real or superficial, as part of coordinated rhetoric, alliance and political movements (Canovan, 2004). Duterte is one such 'new populist' who claims to "represent the right source of legitimate power - the people, whose interests and wishes have been ignored by self-interested political and politically correct intellectuals" (Canovan 2004, p. 242). According to McCoy (2017), such populism takes on a distinctly moral tone as populist leaders claim to act for a 'genuine public' against a 'corrupt elite' that denies the 'will of the people.'

Duterte and others like him deliberately use vulgar, sexist, confrontational and violent language to demonstrate their charisma and power to get the 'job done' at any cost (e.g., controlling crime and activism) and to distance themselves from the 'political establishment', despite themselves often being political elites from wealthy, well-established families (McCoy, 2017). Among countless media scrums and policy addresses, Duterte's violent discourse has given state and non-state actors a sense of legitimacy, authority, and impunity to unleash terror against members of civil society. Duterte's violent rhetoric is exemplified, for example, through statements such as "Just because you're a journalist you are not exempted from assassination, if you're a son of a bitch", in response to the death of a journalist in Manila and high journalist death rates in May 2016 (Lewis, 2016). ${ }^{5}$ Such is Duterte's authoritarian belligerence. His repeat utterances support discursive and structural violence through law and policy and national, provincial and local actors who become emboldened to drive political and economic agendas that accelerate resource plunder through harassment, intimidation and murder. Since 2020, the tempo and scale of authoritarian violence against defenders have been amplified by COVID19 's viral conjunctures.

\section{Viral conjunctures}

The violence against defenders amidst renewed authoritarianism intersecting with COVID-19 restrictions results from a profound conjunctural crisis: a process involving a "... number of forces and contradictions, which are at work in different key practices and sites in a social formation, com[ing] together or 'con-join[ing]' in the same moment and political space..." (Hall, 2011, p. 705). Conjunctural dynamics reflect "period[s] when different social, political, economic and ideological contradictions that are at work in society and have given it a specific and distinctive shape come together, producing a crisis of some kind" (Hall and Massey 2012, p. 55). The intensity of a conjunctural crisis depends on how constraints, contradictions and

\footnotetext{
${ }^{5}$ See https://time.com/4353279/duterte-philippines-journalists-assassination/
} 
violence emerge, collide, and compress over time (Hall 2011, p. 705). In the Philippines, depending on how events, factors and conditions are entangled, crises and violence co-emerge with contrasting tempos among defenders in uneven political economies and the viral atmospheres of COVID-19.

Conjunctural crises yield both slower and faster forms of violence against defenders in the Philippines. Nixon (2011) suggested that slower violence may be gradual and incremental, infrequent or hidden; it is a violence of "delayed destruction that is dispersed across time and space, an attritional violence that is typically not viewed as violence at all" (p. 2). Slow violence is particularly damaging in how it manifests gradually at both the psychological and physical levels. Criminal actors sustain slow violence through intimidation and harassment that develops incrementally and intensifies to envelop NGOs, defenders, families and communities. What the slow violence defenders experience usually develops incrementally and sometimes dissipates, but harassment and intimidation often increase in tempo to co-emerge as faster explosive violence (Nixon, 2011). Harassment and intimidation may accelerate in frequency and severity, causing serious psychological and physical harm and, ultimately, death by murder. In the viral sphere of COVID-19, both slow and fast violence have co-emerged volumetrically through atmospheric particles and uneven political economies, corroding the bodies and lives of defenders in powerful ways.

During the COVID-19 pandemic, violence against defenders has taken on new atmospheric dimensions. Under Duterte's rule, COVID-19 has further driven complex violent atmospheres involving viral clouds, transmission, infection, and containment of activists and others in civil society already marginalised by the ruling elite and the state's security apparatus. As the virus spreads through biological rupture, touch and vapour, it penetrates and reinforces the underlying inequality of predatory capitalist relations, intensifying violent atmospheres through heightened securitisation, suppression and vulnerability among the poor and those defending them and their environments (Lowe, 2010). In rural and urban areas, defenders and other activists who once sought safety by periodically changing travel routes, seeking refuge in 'safe houses', and or carrying out their work under their comrades' protection are now spatially fixed —locked down. They are rendered immobile and easy targets of monitoring and oppression by state and non-state actors. The violence of the virus and those using its existence to legitimatize the suppression of defenders work in ways to envelop, contain and disrupt the everyday lives of activists (Mostafanezhad and Dressler, 2021). Such viral conjunctures penetrate defenders' lives and suppress resistance.

\section{Political economies of violence}

Long after the fall of Dictator President Ferdinand Marcos (1965-1986) —-Duterte's 'strong-man' idol— the suppression of agrarian reform movements, insurgencies and activism in the countryside and cities has continued across the country. Under martial law from 1972 until 1981, Marcos consolidated state and elite control over land, minerals and forest resources in the public domain and under private title, reinforcing landlords' usury practices over tenants and enabling dispossession of indigenous peoples and the killing of those resisting his regime (Putzel, 1992; Vitug, 1993). At that time, the Marcos regime contended with a 'reformed' Communist Party of the Philippines (CPP), which in 1968-1969 drew on Maoist principles and armed resistance through its underground armed 'rebel wing', the New People's Army (NPA). With greater amounts of public land controlled by political elites and militia for commercial agriculture (Kimura, 2006), tenant farmers were evicted and marginalised, while agrarian reform activists and insurgents were killed, defending their rights to land and livelihood. In response to state oppression, corruption, and elite land acquisition, the CPP-NPA insurgency, peasant struggles, and student movements (violently and non-violently) resisted asserting basic human rights and control over land and natural resources (Kimura, 2006; Dressler and Guieb, 2015). Other NGOs and peoples' organization (POs) went underground to forge covert coalitions to resist state subordination and violence against left-leaning activists (Putzel, 1992; Clarke, 1998; Borras and Franco, 2005). The murder of Marcos' political opponent, Benigno 'Ninoy' Aquino, in 1983 and the disappearance and deaths of hundreds of activists soon sparked the popular uprising, the People Power Revolution, which forced Marcos into exile in 1986 (Dressler and Guieb, 2015). 
The wife of Ninoy, Cory Aquino, led the post-Marcos administration from 1986 to 1992. The Aquino administration ushered in new political freedoms and constitutional amendments supporting diverse civil society and state partnerships that forged progressive policies on forest conservation, agrarian reform, and indigenous rights (Dressler, 2009). Sustained pressure from NGOs and peasant movements influenced the Aquino government's (political and legal) reform agenda, for example, through establishing the Comprehensive Agrarian Reform Programme (CARP) in 1988 (Putzel, 1992; Borras and Franco, 2005). The CARP initiative was considered a key policy intervention to quell simmering political tensions and conflicts between landed elites, their military apparatus, and landless classes by redistributing (private and state) Hacienda plantation land to tenant and landless farmers through acquisition and voluntary forms of land transfer (Borras and Franco, 2005, p. 336; Borras, 2008). Despite some initial success, landed political elites slowed the agency from moving forward with market-led land reforms and redistribution (Borras, 2008). Many larger haciendas therefore remained the 'local authoritarian enclaves' that have long entrenched unequal land holdings, fueling peasant grievances, organized social struggles and retaliatory activist murders (Borras, 2008; Wright, 2019).

The policy pivot to the forested uplands - the basis of abating extractivism on indigenous lands-has also been hollowed out and constrained. Despite new laws being drafted to protect indigenous rights to land, resources and social protections under the much-celebrated Indigenous Peoples Rights Act 1997, the issuance of 'native title' through de jure Certificates of Ancestral Domain Title (CADTs) ultimately did less than was hoped for in protecting 'tribal lands' from the expansion of agribusiness and mining in the country (Theriault, 2019). Regardless, CADTs and associated People's Organizations continued to serve as the political and institutional basis for NGOs and indigenous land rights defenders, whose work increasingly collided with the violence of extractive accumulation (Dressler, 2009; Theriault, 2019).

Neoliberal extractivism and violence against defenders and insurgents across the country were particularly pronounced under President Gloria Macapagal Arroyo (GMA) (2001-2010) (Bello et al., 2004; Singh and Camba, 2016). Arroyo pushed multiple biofuel production initiatives on peasant and indigenous fallow lands in Mindanao and Palawan, driving the seizure and consolidation of ancestral lands for palm oil plantations intersecting with, and fueling, local land struggles, social movements and insurgencies (Montefrio and Dressler, 2016; Miller, 2017). ${ }^{6}$ In the early 2000s, the sustained accumulation of resources through dispossession from plantations, mining and timber felling only exacerbated pre-existing social, political and economic inequalities and grievances in the countryside, leading to deeper resistance and increasing numbers of activists and rebels being killed in the south (Dressler, 2017; Dressler, 2021). ${ }^{7}$

The late Benigno 'Noynoy' Aquino III (2010-2016) maintained Arroyo's neoliberal policies. While the political economy of state repression was perhaps less overt, NGOs and defenders still contended with the reproduction of coercive elite politics through subnational political dynasties, local 'political entrepreneurs', and associated militia and assassins enabling extractivism (Fegan, 2002; McCoy, 2002). After Noynoy's six-year term ended, Duterte's 2016 campaign platform of peace and order, resource redistribution and by-passing the 'Manila elite' successfully tapped growing public discontent about the country's weakening welfare state, fraying infrastructure, and rising criminality following decades of neoliberalism (Putzel, 2020; Theriault, 2020). Failing to transcend neoliberalism, Duterte pushed for a 'deregulated' form of authoritarian developmentalism (Jayasuriya, 2020; Ramos, 2021) and associated extra-legal practices that would 'get the job done' for 'the people' (Arsel et al., 2021); that is, the criminalization and eradication of critical media, drug users, leftist NGOs and activists (Putzel, 2020). Over time, Duterte's performative violence has further emboldened state, provincial and non-state actors to harass and kill defenders with impunity while resisting the expansion of Chinese-financed infrastructure (e.g., the Kaliwa dam), illegal timber harvesting, palm oil plantations, and mining into remote frontier areas (McCoy, 2017a; McCoy, 2017b). While the connections between Duterte's authoritarianism and

6 Palm oil development has existed in Mindanao since the 1960-1970s (see Villanueva, 2011; https://news.mongabay.com/2017/08/philippine-palm-oil-plan-equals-corruption-and-land-grabbing-critics-say/)

${ }^{7}$ Under President Arroyo, the NGO Karapatan (2018) noted 194 and 235 extra-judicial killings in 2005 and 2006 , respectively. These deaths include activists and insurgents, whose politics and actions are sometimes blurred in practice or deliberately criminalized by the Philippine National Police, Armed Forces of the Philippines and other right-wing militia. 
provincial level rule are often murky, the current regime's political rhetoric and shared sense of impunity has emboldened violence against defenders at the provincial and local level. The COVID-19 pandemic has further suppressed activism in the country.

\section{Quarantining activism: red-tagging, COVID-19, and resource plunder}

In the lead up to the Duterte government's signing of the Anti-Terrorism Act (RA No 11479) into law on July $3^{\text {rd }}$, 2020, human rights and environmental defenders contended with the convergence of intensifying red-tagging and the violent atmosphere of COVID-19 (Batac, 2020; Chavez, 2020). In March, after the first ECQ was implemented in Metro Manila to contain the COVID-19 outbreak. Hard lockdowns were imposed across the island of Luzon and Mindanao and elsewhere in early April as enforcement agencies and politicians continued to red-tag almost anyone with activist inclinations as potential terrorists (Aspinwall, 2020c, d). In areas where human rights and environmental activism overlap with police or paramilitary guarding mines, plantations or major infrastructure and military-led counter-insurgency campaigns, ECQ restrictions have been accompanied by military and police surveillance, harassment and arrests (Jennings, 2020). Once in lockdown, many activists have received unexpected and unwanted visits from enforcement units with violent consequences. Many arrests have occurred at police checkpoints at so-called quarantine 'boundary zones' or during household visits late at night while 'suspects' were sleeping under lockdown. ${ }^{8}$

Many state enforcers have used the Anti-Terror Bill in conjunction with ECQ restrictions to enhance monitoring and containment measures, with COVID-19 related restrictions being imposed upon defenders erratically and subjectively, reinforcing their suppression by claiming they have breached quarantine. The frequency of such arrests shows that authorities have regularly used pandemic-related restrictions monitor, control and suppress defenders (Aspinwall, 2020c). Based on the news media analysis (covering 'center-left' and 'right-wing' national media and 'alternative' left-wing media) from March to December 2020, when quarantine measures were strictest, 44 incidents involving a total of 134 people occurred, including individual and group arrests, harassment and deaths of defenders. Among the 44 incidents, 13 cases were directly associated with authorities taking advantage of quarantine measures (see Table 2).

\begin{tabular}{|l|c|c|c|}
\hline \multicolumn{1}{|c|}{ Type of incident } & $\begin{array}{c}\text { No of incidents } \\
\text { reported }\end{array}$ & No. of persons involved & $\begin{array}{c}\text { Cases involving COVID-19 } \\
\text { restrictions }\end{array}$ \\
\hline Arrest & 12 & 91 & 5 \\
\hline Death & 16 & 27 & 1 \\
\hline Detention & 1 & 1 & 1 \\
\hline Kidnapping & 1 & Not specified & 1 \\
\hline Other harassment & 3 & 9 & 1 \\
\hline Smear campaign & 2 & 2 & 13 \\
\hline Intimidation & 4 & 1 & \\
\hline Assault & 1 & & 134 \\
\hline $\begin{array}{l}\text { Environmental } \\
\text { degradation and } \\
\text { harassment }\end{array}$ & 4 & & \\
\hline Total & 4 & & \\
\hline
\end{tabular}

Table 2: COVID-19 related violence against defenders in 2020.

\footnotetext{
${ }^{8}$ In other cases, community quarantine measures have made it increasingly difficult for thousands of poor urban and rural dwellers to rely on collective labor across different locations to sustain typically diverse livelihoods and income sources, thereby forcing many to violate curfews, over-exploit natural resources and be fined or imprisoned.
} 
The 91 individual arrests typically involved police detaining and arresting small-to-medium-sized groups of (six or so) activists who were on their way to protest or were actively protesting the deaths and harassment of fellow defenders. Five of these cases were justified based on activists allegedly breaching COVID-19 lockdown rules. The high number of deaths (27 individuals from 16 incidents) was partly due to smaller groups of (3-5) activists being slain by police and/or the military (in one-way or two-way firefights) and individual activists being assassinated in cold blood on their way to work or when at home in lockdown, complying with state public health measures.

Based on the detailed media search, 13 reported incidents were directly associated with state authorities (e.g., national police) using pandemic restrictions and programs to arrest, relocate and/or harass and intimidate activists involved in social and environmental justice campaigns. Among all types of incidents, arrests were most prominent and the main method of containing activists during regional lockdowns from March to June 2020. Indeed, it was at this time, during a national address, that Duterte warned leftist groups and violators of the ECQ not to challenge the government (Esguerra, 2020): ${ }^{9}$

Don't do anything foolish and go on a riot because I will order you detained, and I will let you go after this COVID-19.

He added:

Don't test the Filipino. Do not try to test it. You know, we are ready for you. Violence or shooting or killing, I will not hesitate to order my soldiers to shoot you. I will not hesitate to order the police to arrest and detain you.

\section{Violent vignettes}

Given that the media search identified prominent cases deemed worthy of media attention, the above enumerations likely underestimate the actual number of incidents that occurred during and after lockdown measures were in place. Below I illustrate some of the more prominent cases involving state authorities, including the arrest of activists protesting the murder of their colleagues, indigenous Lumad children being detained for a return migrant program during the initial lockdown, and activists being arrested while delivering relief goods to poor families during the extended lockdown. Most examples involve the police using quarantine restrictions to detain and arrest activists for supposedly disseminating anti-government, communist propaganda material (embedded in relief goods).

On May 1, 2020, in Iloilo, the Visayas, the police reportedly arrested 40 activists attempting to protest the recent murder of Bayan Muna coordinator Jory Porquia, citing their violation of COVID-19 quarantine rules (Rappler, 2020a). ${ }^{10}$ Working as a coordinator for the political organization 'Bayan Muna' (literally 'Nation First'), an affiliated member of the leftist political party Makabayan, Porquia was shot by four armed men in Iloilo City. Before his murder, Porquia had claimed that local police had repeatedly harassed him for leading relief operations and education campaigns on COVID-19 in poor communities in Iloilo City (Rappler, 2020b). ${ }^{11}$ Just as his murderer and deeper political context of his death remain unknown-apart from assertively pushing for land reform and regularly being red-tagged as a CPP-NPA sympathizer-those planning to protest his murder were arrested by the police allegedly after agreeing to disperse. The police cordoned off, arrested, and carried off in a truck approximately 40 young activists for 'processing.'

\footnotetext{
${ }^{9}$ See https://newsinfo.inquirer.net/1252557/duterte-warns-left-vs-challenging-govt-amid-covid-19-crisis-i-will-order-youdetained

${ }^{10}$ See https://www.rappler.com/nation/iloilo-cops-arrest-activists-protesting-bayan-muna-coordinator-murder

${ }^{11}$ See https://www.rappler.com/nation/they-shot-my-tatay-nine-times-jory-porquia
} 
First reported June 18, 2020, the military allegedly detained two young indigenous Lumad students after leaving their school supposedly on the premise that during the pandemic, the youth were hoping to participate in the 'balik-probinsiya' (B2P) program in Sarangani province, Mindanao, a state program aimed at reversing rural peoples' migration to Metro Manila and other urban areas (San Juan, 2020). ${ }^{12}$ The father of the two youth was then arrested by the same unit after apparently asking for his children's whereabouts. Collectively detained and missing, the Lumad organization Save Our Schools network issued an alert that the three had last been seen boarding a police vehicle after leaving the premises of Mindanao Interfaith Services Foundation (MISFI), the school the youth had attended. In this incident, the premise of needing to contain and return citizens during the pandemic was apparently used by the authorities to detain Lumad youth who are often (erroneously) associated with the NPA and other leftist political groups opposed to the intensifying expansion of mining and plantations in Mindanao.

In an even more brazen case, between April 19-21, 2020, several volunteers from the left-wing rightsgroup Anakpawis - a party-list of the electoral wing of the radical trade union movement, Kilusang Mayo Uno and the peasant group Kilusang Mangbubulid ng Pilipinas - were arrested and charged by state authorities for alleged violation of a pandemic-related law (the Republic Act 11332 or the Mandatory Reporting of Notifiable Diseases and Health Events of Public Health Concern Act) and for 'Inciting to Sedition' (Condelund, 2020). ${ }^{13}$ Bulacan police stopped a group of six volunteers at a checkpoint who were then brought to a municipal police station where their food pass (for food relief distribution), allegedly along with copies of activist newspapers, was confiscated. The group was reportedly mishandled for supposedly giving out anti-government propaganda material (Luna, 2020). ${ }^{14}$ The Department of Interior and Local Government (DILG) undersecretary accused the group of using an unauthorized government-issued pandemic food pass in an attempt to spread 'seditious, subversive propaganda' and to conduct a mass gathering under the broader guise of a COVID-19 food relief operation. An Anakpawis member who attempted to negotiate the release of the volunteers was then included in the charge. A lawyer for the peasant rights group, SENTRO, disputed the arrest, calling it unlawful, saying that the group did not violate the law, as they were providing food relief with a proper pass. The food drive was part of a larger food relief effort organized by a diverse coalition of rights groups, peasant farmer groups and other advocates to link farm produce with the poor affected by the COVID-19 lockdown.

In Bacoor, Cavite - a commuter mega-city near Metro Manila-local resistance to coastal land reclamation for developing a new Chinese-financed international airport and waterside residential communities in Cavite was met with early morning police patrols targeting community leaders opposing the broader project. Local fisherfolk and leftist NGOs, such as Pamalakaya, which supports fisher rights and livelihoods, suggested that the land reclamation would significantly damage coastal areas, requiring the demolition of local residences and destruction of remnant mangrove areas, critical spawning habitats for declining marine species and livelihoods in the area. Local activists claimed that the state Department of Environment and Natural Resources (DENR) took advantage of the COVID-19 lockdown to fast-track the issuance of the Environmental Clearance Certificate needed to allow the development to proceed, just as organized protests at the developments were banned, supposedly because of community quarantine policies (Aspinwall, 2020e). ${ }^{15}$

In resistance to earlier development in the area, Pamalakaya has suggested that the homes in fishing communities were set ablaze by suspected arsonists to make way for the Cavite expressway, which runs along the reclaimed coastal lands. The violence in this case runs deep. Pamalakaya's own former members and consultants who had resisted the developments were repeatedly red-tagged as alleged communist terrorists and some were murdered: Randall Echanis was stabbed to death in Manila in August 2020 (Aspinwall, 2020d).

\footnotetext{
${ }^{12}$ See https://www.philstar.com/nation/2020/06/18/2021759/lumad-students-reported-missing-are-military-camp-report

${ }^{13}$ See https://www.rappler.com/nation/ex-anakpawis-congressman-relief-drive-volunteers-charged-sedition-april-2020

14 See https://www.philstar.com/headlines/2020/04/21/2008760/critical-not-seditious-journalist-artists-say-papers-haltedbulacan-relief-drive

${ }^{15}$ See https://chinadialogue.net/en/cities/manilas-new-airport-land-reclamation-controversey/
} 
In most cases, the harassment and intimidation of defenders are outcomes of historical struggles between peasant movements and activists and landed elites and urban politicians. The military, police and paramilitary often work on the latter's behalf, driving violent land grabs, dispossession, and murder that allow the politically powerful to retain and accumulate land and capital. The same is true for Palawan Island in the southwestern Philippines.

\section{COVID-19, censure and resource plunder on Palawan Island}

As defenders have been subject to the burden of political oppression working through quarantine measures, they have been unable to continue their monitoring, enforcement, and engagement work. Cases from Palawan (separate from the media review above) reveal how state actors, corporate brokers, local henchmen, and criminals have exploited lulls in enforcement to intensify the red-tagging and political censure of activists, the exploitation of timber and coastal resources, and the broader deregulation of extractive sectors. Such deregulation aims to enable the expansion of mining tenements as part of the country's post-COVID recovery strategy.

Activists, NGOs, and the provincial government body, the Palawan Council for Sustainable Development (PCSDs) — charged with regulating resource access and use within and beyond the Province's Environmental Critical Areas Network (ECAN) zones-have long been at odds with one another. However, political contestations among the PCSDs, NGOs and defenders have intensified in the context of Duterte's culture of impunity and COVID-19 restrictions. In particular, a historical political feud between the fiery activist leader of the NGO, Palawan NGO Network Incorporated (PNNI), Attorney Bobby Chan, and the group comprising the PCSDs, the Provincial Board, and a former logging baron, now governor, recently spilled over in dramatic fashion.

In the July 2020 lockdown, the PNNI and PCSD strategically used social media to accuse one another of insufficient environmental monitoring and protection due to the lockdown. PNNI and other NGOs pointed out that with many of their staff in quarantine, significant increases in mangrove and timber deforestation were occurring in northern and southern Palawan (Fabro, 2020), ${ }^{16}$ particularly in the higher elevation (>800 m asl) 'core zones' under the PCSD's ECAN jurisdiction. As the smear campaigns intensified, the provincial board drafted a formal resolution declaring Attorney Chan, 'persona non grata' (Laririt and Magdayao, 2021) ${ }^{17}$ broadly equivalent to red-tagging, based on supposedly 'slandering' the work of the PCSDs and provincial government in a Vimeo cast for a defender funding campaign two years earlier. ${ }^{18}$

As illegal resource uses continued across upland forests, coastal areas and oceans, the PCSD and the DENR soon responded to President Duterte's push to lift a nine-year moratorium on granting new mining permits in the Philippines as part of the country's COVID-19 recovery strategy. Signed into force on April 14, 2021, Executive Order 130 was meant to revive the country's ailing economy by reinvigorating nickel mining across the country, particularly on Palawan's steep southern mountain chains (Chavez, 2021). ${ }^{19}$ With new mineral agreements on the table, the PCSD announced plans to review the criteria by which the ECAN's core and restricted zones are designated, noting that "the probable amendments of the implementing guidelines of ECAN are projected to somehow reduce the restraints on many industries from operating in Palawan." ${ }^{20}$ PNNI's Chan and other defenders quickly pointed out that the PCSD's aim was in effect to modify the designation of 'no-touch' core zones (meant strictly for forest conservation and watershed protection) into controlled or multiple-use zones that would allow for timber clearing and the expansion of mining activities. Another NGO, the Environmental Legal Assistance Center Inc, noted critically that:

\footnotetext{
${ }^{16}$ See https://www.rappler.com/nation/illegal-logging-continues-mimaropa-despite-luzon-lockdown

${ }^{17}$ See https://palawan-news.com/palawan-environmental-ngo-leader-declared-persona-non-grata-by-province/

${ }^{18}$ See https://gogetfunding.com/defenders-of-the-philippines-last-ecological-frontier/

${ }^{19}$ See https://news.mongabay.com/2021/04/complete-turnaround-philippines-duterte-lifts-ban-on-new-mining-permits/

${ }^{20}$ See https://www.facebook.com/pcsd7611/photos/a.355182424691142/1593722484170457/?type=3
} 
[We are] ...deeply concerned that this new EO [Executive Order] will give impetus to existing mining companies to actively pursue their applications for expansion of their mining areas in Palawan. It will likewise further open up Palawan's natural forests, key biodiversity areas, watersheds and ancestral domains to extractive activities. Almost all of the nickel mining areas in Palawan are natural forests which are considered areas of maximum protection or core zones under the Strategic Environmental Plan for Palawan (RA 7611). Currently, there are plans pending before the Palawan Council for Sustainable Development (PCSD) to change the core and restricted zones (under the SEP's environmentally critical areas network or ECAN zoning) into multiple use zones in order to accommodate mining projects. (ELAC, 2021) ${ }^{21}$

Not long after these Palawan-based NGOs began their social media campaign against the lifting of the mining moratorium, another episode of illegal timber clearing took place at Pyramid Hill Mining's 5,149 ha concession, which overlaps the ancestral lands of the indigenous Pala'wan in the island's south. Amidst the protests against the sustained deforestation in upland areas, Jean Feliciano, the anti-mining activist Mayor of Brookes Point town in southern Palawan, was censured and suspended from Mayoral duties by the Office of the Ombudsman due to assertive protests against the illegal clearing of 25,000 ha of trees by Ipilan Nickel Corporation in 2018. The fact that she was suspended from office for a year without pay just as Duterte's office signed Executive Order 130 was no coincidence. The suspension was designed to instill fear into the hearts and minds of defenders resisting the plunder of the island (Ocampo and Miranda 2021). ${ }^{22}$

Under Duterte's regime, informal and formal censures have done nothing less than publicly criminalize defenders like Chan, Feliciano, PNNI and partner NGOs and ultimately legitimatize their harassment and intimidation and, worse, drive death by murder. In this way, slow violence emerges as fast and deadly violence against defenders.

\section{Discussion and Conclusion}

Building on a long history of authoritarian tendencies in the Philippines, President Duterte's coercive populism has reinforced earlier political economies of violence to embolden the military, police, and assassins to further unleash violence across the country. In the twilight of his six-year term, Duterte has enabled and intensified the violent red-tagging of Filipino defenders as leftist 'anti-capitalists' and presumed sympathizers of the CPP-NPA. Endured by defenders like Chan and Feliciano, red-tagging and similar censures are now entrenched in the country as part of a system of surveillance and intimidation that drives incremental harassment, intimidation and, ultimately, the murder of activists. Activism is increasingly synonymous with terrorism in the country. In this violent atmosphere, the government's new Anti-Terrorism Act (RA No 11479) has deliberately (and now legally) conflated terrorism and activism in practice and intensified the ongoing suppression of citizen rights and freedoms. Since 2016 in Duterte's Philippines, the corrosive atmosphere of impunity has allowed enforcement agencies, politicians, and others to red-tag almost anyone with activist inclinations as a potential terrorist, legitimatizing harassment, and murder. Amidst the country's pre-existing violent political economy, the election of Duterte and his authoritarian governance reflect a definitive conjunctural moment involving entanglements of toxic ideology, rhetoric and patron-client relations that drives violence against human rights, the environment, and those protecting both in rural and urban areas (see Theriault, 2020).

Since March 2020, defenders' struggles under Duterte's authoritarian regime have intersected with the violent atmospheres of COVID-19 (Aspinwall, 2020c; Mostafanezhad and Dressler, 2021). Affected by sustained, emergency quarantines, the already dangerous work of defender activism has been subjected to intensified monitoring, restrictions and violence across the country. Those enabling Duterte's agenda have used the viral spread of COVID-19 and quarantine laws to intensify the suppression of activism, enabling spatially concentrated forms of harassment, arrests, and murder of defenders in the country (Nixon, 2011). Using COVID-19 health checkpoints and lockdown rules (e.g., home quarantine, curfews, etc), state authorities have stopped, contained and arrested activists suspected of aligning with the CPP-NPA and broadly prohibited

\footnotetext{
${ }^{21}$ See https://www.facebook.com/453671728086434/posts/3835102959943277/?d=n

22 See https://newsinfo.inquirer.net/1448063/mayor-vs-mining-guilty-of-oppression
} 
assembly for protest against mega-infrastructure that threatens vulnerable livelihoods, citing breaches of COVID-19 health regulations. The current mix of authoritarian clampdowns and COVID-19 lockdowns has instilled growing fear and resentment in civil society and deep anxiety among the poor, who often rely on NGO support for livelihood provisions during the viral crisis. As the rural and urban poor find food supply lines being cut due to government checkpoints slowing or blocking food deliveries or by having their mobility curtailed, they are also criminalized for activism or other socially 'deviant' behaviors. The resulting levels of social, economic and physical precarity are profound (Mongabay, 2020). ${ }^{23}$ Given the uncertainty, the fear and fallout resulting from such violent atmospheres will only intensify.

On Palawan Island, state authorities, civil society and defenders find themselves in a deepening political imbroglio involving censure, violence, and accelerating resource plunder during the COVID-19 pandemic. With repressive lockdown measures in place, defenders cannot protect the social and environmental safeguards such as the ECAN zoning system - that have maintained forest cover, biodiversity and, in many ways, indigenous livelihoods as state actors have attempted to deregulate the mining sector and illegal operators have intensified the plunder of resources across the island. As the intimidation, harassment and murder of defenders continue on Palawan amidst state actors flouting their own laws and accruing wealth from lands and largesse, the future of the island and those who protect it appears grim indeed.

Authoritarian rule and violence against defenders have been dramatically amplified as the right to movement and access and, thus protest, is quarantined. As COVID-19 articulates with the violent political economy of Duterte's administration, many defenders across the country find themselves in an increasingly uncertain and vulnerable circumstances, where constitutionally enshrined civil liberties afford them few, if any, protections and redress. As COVID-19 lingers into 2021 (and possibly 2022 and 2023) and vaccinations are given slowly and unevenly, the activists who fight for poor people's right to secure a livelihood and a dignified life will undoubtedly suffer again from the harassment and murder of 2020. The question therefore remains: from where will redress and justice come?

\section{References}

Arsel, M., Adaman, F., \& Saad-Filho, A. (2021). Authoritarian developmentalism: The latest stage of neoliberalism? Geoforum. https://doi.org/10.1016/j.geoforum.2021.05.003

Aspinwall, N. (2020a). Mindanao After Martial Law. The Diplomat. March 10, 2020. https://thediplomat.com/2020/03/mindanao-after-martial-law/ Accessed November 2020.

Aspinwall, N. (2020b). Philippine Court asked to annul anti-terror law amid concerns it will target dissidents. The Diplomat. https://thediplomat.com/2020/07/philippine-court-asked-to-annul-anti-terror-law-amidconcerns-it-will-target-dissidents/

Aspinwall, N. (2020c). The Philippines' Coronavirus lockdown is becoming a crackdown. The Diplomat. https://thediplomat.com/2020/04/the-philippines-coronavirus-lockdown-is-becoming-a-crackdown/ Accessed November 2020.

Aspinwall, N. (2020d). The killings in the Philippines grow more brazen. The Interpreter. https://www.lowyinstitute.org/the-interpreter/killings-philippines-grow-more-brazen

Aspinwall, N. (2020e). Manila's new China-backed airport bogged down by land reclamation controversy. China Dialogue. $\quad$ https://chinadialogue.net/en/cities/manilas-new-airport-land-reclamationcontroversey/

Batac, M. (2020). The Philippines' Anti-terror Bill is poised to cause more terror. Opinion. https://www.aljazeera.com/opinions/2020/6/25/the-philippines-anti-terror-bill-is-poised-to-cause-moreterror/ June 25, 2020.

\footnotetext{
${ }^{23}$ See https://news.mongabay.com/2020/05/deaths-arrests-and-protests-as-philippines-re-emerges-from-lockdown/ See also: https://newsinfo.inquirer.net/1252003/dilg-dismantle-all-checkpoints
} 
Beban, A., Schoenberger, L., \& Lamb, V. (2020). Pockets of liberal media in authoritarian regimes: What the crackdown on emancipatory spaces means for rural social movements in Cambodia. The Journal of Peasant Studies, 47(1), 95-115. https://doi.org/10.1080/03066150.2019.1672664

Bello, W. (2019). Counterrevolution: The global rise of the Far Right. Fernwood Publishing.

Bello, W., Docena, H., de Guzman, M., and Malig, M. (2004). The anti-development state: The political economy of permanent crisis in the Philippines. Zed.

Borras, S.M. (2008). Competing views and strategies on agrarian reform: International perspective. Ateneo de Manila University Press.

Borras Jr, S. M., and Franco, J. C. (2005). Struggles for land and livelihood: redistributive reform in agribusiness plantations in the Philippines. Critical Asian Studies, 37(3), 331-361.

Borras, S, and Franco, J. (2013). Global land grabbing and political reactions 'from below". Third World Quarterly. 34(9), 1723-1747.

Bugaric, B. (2019). The two faces of populism: Between authoritarian and democratic populism, German Law Journal, 20, 390-400. https://doi.org/10.1017/glj.2019.20

Canovan, M. (2004). Populism for political theorists? Journal of Political Ideologies, 9(3), 241-252.

Chavez, C. (2020). Local officials voluntarily back Anti-Terrorism Bill. Manila Bulletin. https://mb.com.ph/2020/06/17/local-officials-voluntarily-back-anti-terrorism-bill-dilg/

Chavez, L. (2021). 'Complete turnaround': Philippines' Duterte lifts ban on new mining permits. Mongabay. April 15, 2021. https://news.mongabay.com/2021/04/complete-turnaround-philippines-duterte-lifts-banon-new-mining-permits/ Accessed July 1, 2021

Clarke, G. (1998). The politics of NGOs in South-East Asia: Participation and protest in the Philippines. Routledge.

Clarke, J. (2014). Conjunctures, crises, and cultures: valuing Stuart Hall. Focaal, 70, 113-122.

Conde, M. (2020). Ex-Anakpawis congressman, relief drive volunteers charged with sedition. Rappler News. April 21 2020. https://www.rappler.com/nation/ex-anakpawis-congressman-relief-drive-volunteerscharged-sedition-april-2020

Curato, N. (2016). Politics of anxiety, politics of hope: penal populism and Duterte's rise to power. Journal of Current Southeast Asian Affairs, 35(3), 91-109. https://doi.org/10.1177/186810341603500305

Delina, L. L. (2020). Indigenous environmental defenders and the legacy of Macli-ing Dulag: Anti-dam dissent, assassinations, and protests in the making of Philippine energyscape. Energy Research \& Social Science, 65, 101463. https://doi.org/10.1016/j.erss.2020.101463

Dressler, W. H. (2009). Old thoughts in new ideas: State conservation measures, livelihood and development on Palawan Island, the Philippines. Ateneo de Manila University Press.

Dressler, W. H. (2017). Contesting moral capital in the economy of expectations of an extractive frontier. Annals of the American Association of Geographers, 107(3), 647-665. https://doi.org/10.1080/24694452.2016.1261684

Dressler, W. (2021). Defending lands and forests: NGO histories, everyday struggles, and extraordinary violence in the Philippines. Critical Asian Studies, 0(0), 1-32. https://doi.org/10.1080/14672715.2021.1899834

Dressler, W. H., \& Guieb III, E. R. (2015). Violent enclosures, violated livelihoods: environmental and military territoriality in a Philippine frontier. Journal of Peasant Studies, 42(2), 323-345.

ELAC (2021) Environmental Legal Assistance Center, Inc. Reflections on Statement on the Lifting of Mining Moratorium (Executive Order 130). April 15, 2021, ELAC Facebook page

Esguerra, D. (2020). Duterte warns left, troublemakers vs challenging gov't amid COVID-19 crisis: I will order you shot. Philippine Daily Inquirer. April 1, 2020. https://newsinfo.inquirer.net/1252557/duterte-warnsleft-vs-challenging-govt-amid-covid-19-crisis-i-will-order-you-detained. Accessed July 8, 2021.

Fabro, A. (2020). Illegal logging continues in MIMAROPE despite Luzon lockdown. Rappler News. https://www.rappler.com/nation/illegal-logging-continues-mimaropa-despite-luzon-lockdown 
Fegan, B. (2002). Entrepreneurs in votes and violence: Three generations of a peasant political family. In McCoy, A. (Ed.). An anarchy of families: State and family in the Philippines. (pp. 33-107). Ateneo de Manila University Press.

Global Witness. (2014). Deadly environment: the dramatic rise in killings of environmental and land defenders. Global Witness. Retrieved from https://www.globalwitness.org/en/campaigns/environmentalactivists/deadly-environment/

Global Witness. (2018). At What Cost? Irresponsible business and the murder of land and environmental defenders in 2017. Global Witness.

Global Witness. (2019). Enemies of the State? How governments and business silence land and environmental defenders. Global Witness.

Hall, S. (1979). The great Moving Right show. Marxism Today, Jan, 14-20.

Hall, S. (2011). The neo-liberal revolution. Cultural Studies, 25(6), 705-728.

Hall, S., and Massey, D. (2012). Interpreting the crisis. In: Rutherford J. and Davison S. (eds.). The neoliberal crisis. Lawrence and Wishart.

Heydarian, R. (2017). Tragedy of small power politics: Duterte and the shifting sands of Philippine foreign policy, Asian Security, 13(3), 220-236.

Holden, W., Nadeau, K., \& Jacobson, R. D. (2011). Exemplifying accumulation by dispossession: Mining and indigenous peoples in the Philippines. Geografiska Annaler: Series B, Human Geography, 93(2), 141161. https://doi.org/10.1111/j.1468-0467.2011.00366.x

Jayasuriya, K. (2020). The rise of the right: Populism and authoritarianism in Southeast Asian politics. Southeast Asian Affairs, 2020(1), 43-55.

Jennings, R. (2020). Philippines denies claim of increase police drug-related killings. East Asia Pacific. https://www.voanews.com/east-asia-pacific/philippines-denies-claim-increased-police-drug-relatedkillings. Accessed Jan $4^{\text {th }} 2021$.

Kimura, M. (2006). The Federation of Free Farmers and its significance in the history of the Philippine peasant movement. Japanese Journal of Southeast Asian Studies, 44(1), 3-30.

KPNE (2019). Taking lands, taking lives. Kalikasan People's Network for the Environment report on human rights and environment defenders and climate change. Quezon City, Philippines.

Laririt, P. and Magdayao, A. (2021). Palawan environmental NGO leader declared 'persona non grata' by province. Palawan News. January 12 ${ }^{\text {th }}$ 2021. https://palawan-news.com/palawan-environmental-ngoleader-declared-persona-non-grata-by-province/ Accessed April 2021.

Lewis, S. (2016). Duterte says journalists in the Philippines are 'not exempted from assassinations.' Time Magazine. June $1^{\text {st }}$. 2016. Accessed July 8, 2021. https://time.com/4353279/duterte-philippinesjournalists-assassination/

Lowe, C. (2010). Viral clouds: becoming H5N1 in Indonesia. Cultural Anthropology, 25(4), 625-649.

Luna, F. (2020). 'Critical but not seditious', journalists, artists say of paper in halted Bulacan relief drive. PhilStar April 21 2020 . https://www.philstar.com/headlines/2020/04/21/2008760/critical-notseditious-journalist-artists-say-papers-halted-bulacan-relief-drive Accessed October 2020

McCarthy, J. (2019). Authoritarianism, populism, and the environment: comparative experiences, insights, and perspectives. Annals of the American Association of Geographers, 109(2), 301-313. https://doi.org/10.1080/24694452.2018.1554393

McCoy, A. W. (2002). An anarchy of families: state and family in the Philippines. Ateneo de Manila University Press.

McCoy, A. W. (2017a). Philippine populism: Local violence and global context in the rise of a Filipino strongman. Surveillance \& Society, 15(3/4), 514-522. https://doi.org/10.24908/ss.v15i3/4.6638

McCoy, A. W. (2017b). Global populism: a lineage of Filipino strongmen from Quezon to Marcos and Duterte. Kasarlinlan: Philippine Journal of Third World Studies, 32(1-2), 7-54. 
Middeldorp, N., \& Billon, P. L. (2019). Deadly environmental governance: authoritarianism, eco-populism, and the repression of environmental and land defenders. Annals of the American Association of Geographers, 109(2), 324-337. https://doi.org/10.1080/24694452.2018.1530586

Miller, B. (2017). Philippine palm oil plan 'equals corruption and land-grabbing' critics say. Mongabay Series: Global Palm Oil. https://news.mongabay.com/2017/08/philippine-palm-oil-plan-equals-corruption-andland-grabbing-critics-say/ Accessed November 2020.

Moffitt, B., \& Tormey, S. (2014). Rethinking populism: Politics, mediatisation and political style. Political Studies, 62(2), 381-397.

Mongabay (2020). Deaths, arrests and protests as Philippines remerges from lockdown. Mongabay Series: Endangered Environmentalists. https://news.mongabay.com/2020/05/deaths-arrests-and-protests-asphilippines-re-emerges-from-lockdown/

Moore, J. W. (2000). Sugar and the expansion of the early modern world-economy: commodity frontiers, ecological transformation, and industrialization. Review (Fernand Braudel Center), 23(3), 409-433.

Montefrio, M.J.F. (2014). Growing low-carbon commodities in upland Philippines: Integration of smallholders in biofuels and rubber production regimes. PhD dissertation, State University of New York.

Montefrio, M.J.F. and Dressler, W. H. (2016). The green economy and constructions of the "idle" and "unproductive" uplands in the Philippines. World Development, 79, 114-126.

Mostafanezhad, M., \& Dressler, W.H. (2021). Violent atmospheres: Political ecologies of livelihoods and crises in Southeast Asia. Geoforum. https://doi.org/10.1016/j.geoforum.2021.05.010

Neimark, B., Childs, J., Nightingale, A. J., Cavanagh, C. J., Sullivan, S., Benjaminsen, T. A., Batterbury, S.P.J., Koot, S., \& Harcourt, W. (2019). Speaking power to "post-truth": Critical political ecology and the new authoritarianism. Annals of the American Association of Geographers, 109(2), 613-623. https://doi.org/10.1080/24694452.2018.1547567

Nixon, R. (2011). Slow violence and the environmentalism of the poor. Harvard University Press.

Ocampo, K., and Miranda, R. (2021). Mayor vs mining 'guilty of oppression'. Philippine Daily Inquirer. June 19 . https://newsinfo.inquirer.net/1448063/mayor-vs-mining-guilty-of-oppression Accessed July 12021

OHCHR (2020). Report of the United Nations High Commissioner for Human Rights on the Situation of human rights in the Philippines. Human Rights Council, Annual report of the United Nations High Commissioner for Human Rights and reports of the Office of the High Commissioner and the SecretaryGeneral.

PCSDs (2021). Palawan Council for Sustainable Development Facebook page. April 13, 2021. https://www.facebook.com/pcsd7611/photos/a.355182424691142/1593722484170457/?type=3 Accessed June 10, 2021

Palo, A., Rosetes, M., and Cariño, D. 2020. COVID-19 and food system in the Philippines. In COVID-19 and food systems in the Indo-Pacific. An assessment of vulnerability, impacts and opportunities for action. ACIAR Technical Report 96. Australian Government, ACIAR.

Putzel, J. (1992). A captive land: the politics of agrarian reform in the Philippines. Monthly Review Press.

Putzel, J. (2020). The 'populist' right challenge to neoliberalism: Social policy between a rock and a hard place. Development and Change 51(2): 418-441.

Ramos, C. G. (2021). The return of strongman rule in the Philippines: Neoliberal roots and developmental implications. Geoforum. https://doi.org/10.1016/j.geoforum.2021.04.001

Rappler (2020a). IIoilo cops arrest 40 activists protesting murder of Bayan Muna coordinator. Rappler News. May 1 2020. See https://newsinfo.inquirer.net/1252557/duterte-warns-left-vs-challenging-govt-amidcovid-19-crisis-i-will-order-you-detained Accessed November 2020.

Rappler (2020b). They shot my tatay nine times. Rappler News. April $30^{\text {th }}$. https://www.rappler.com/nation/they-shot-my-tatay-nine-times-jory-porquia. Accessed November 2020. 
Rutten, R. (2008). Brokering a revolution: Cadres in a Philippine insurgency. Ateneo de Manila University Press.

San Juan, R. (2020). Lumad students reported missing are in military camp - report. Philstar.com June $18^{\text {th }}$. https://www.philstar.com/nation/2020/06/18/2021759/lumad-students-reported-missing-are-militarycamp-report Accessed October 2020.

Scoones, I., Edelman, M., Borras, S.M., Hall, R., Wolford, W., and White, B. (2018). Emancipatory rural politics: confronting authoritarian populism. The Journal of Peasant Studies 45(1), 1-20.

Singh, J.T.N. and Camba, A. A. (2016). Neoliberalism, resource governance and the everyday politics of protests in the Philippines. In: Elias, J. \& Rethel, L. (Eds.), The everyday political economy of Southeast Asia, (pp. 49-71). Cambridge University Press. http://doi.org/10.1017/CBO9781316402092.003

Theriault, N. (2019). Unravelling the strings attached: Philippine indigeneity in law and practice. Journal of Southeast Asian Studies, 50(1), 107-128.

Theriault, N. (2020). Euphemisms we die by: On eco-anxiety, necropolitics, and green authoritarianism in the Philippines. In Maskovsky, J., and Bjrok-James, S. (Eds.), Beyond populism: angry politics and the twilight of neoliberalism (pp. 182-205). West Virginia University Press.

UNE (2018). Who are environmental defenders? UN Environment. United Nations Environment. https://www.unenvironment.org/fr/node/21162 (accessed April 28, 2020)

Villanueva, J. (2011). Oil palm expansions in the Philippines. Analysis of land rights, environment and food security issues. In: Colchester, M. and Chao, S. with with Dallinger, J., Sokhannaro, H.E.P., Vo Thai Dan, V. and Villanueva. J. (Eds.), Oil palm expansion in South East Asia. (pp. 110-216). Forest Peoples Programme and Perkumpulan Sawit Watch.

Vitug, M. D. (1993). Power from the forest: the politics of logging. Philippine Center for Investigative Journalism.

Wright, S. (2019). Towards an affective politics of hope: Learning from land struggles in the Philippines. Environment and Planning $\mathrm{E}$ Nature and Space. https://journals.sagepub.com/doi/abs/10.1177/2514848619867613 